\title{
Pozitív családtervezéssel kapcsolatos ismeretek
}

\author{
Knowledge of positive family planning
}

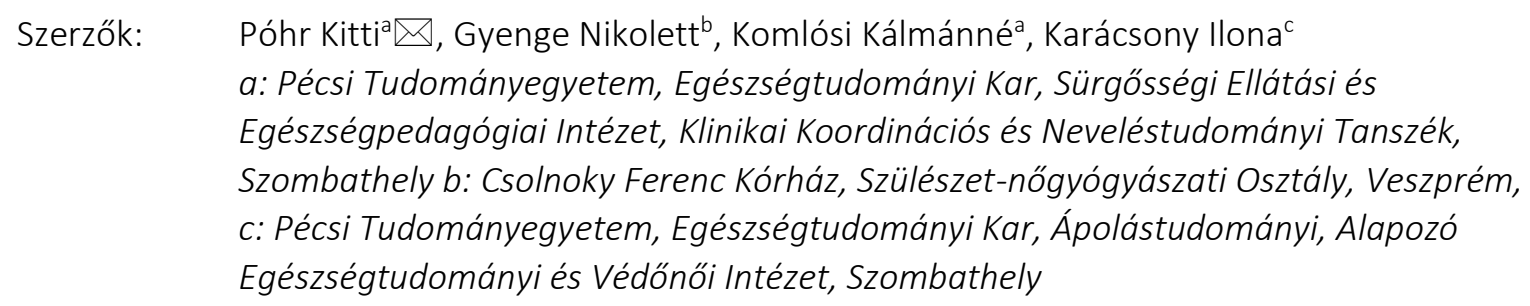

Beküldve: 2019. 03. 02.

doi: $\quad$ 10.24365/ef.v60i2.432

\begin{abstract}
Összefoglaló:
Bevezetés: Jelen vizsgálat célja a 14-18 éves fiatalok ismereteinek, információforrásainak, jövőképének vizsgálata a családtervezés területén belül.

Módszertan: A kvantitatív, keresztmetszeti kutatást egy veszprémi és egy tapolcai középiskolában végeztük 2017-ben. Nem véletlenszerű, kényelmi mintavétel során nappali rendszerű középfokú oktatásban tanuló diákok $(n=182)$ töltötték ki a saját szerkesztésú kérdőívet. Az adatok elemzéséhez a leíró statisztika mellett két változó összefüggéseinek megállapítására khí-négyzet próbát alkalmaztunk $(p<0,05)$.

Eredmények: A megkérdezettek nembeli megoszlása közel azonos, több, mint felük legalább két gyermeket tervez. Családtervezéssel kapcsolatos ismerethez több forrásból jutottak a fiatalok, a családtól a tanulók mintegy $80 \%$-a, az iskolától és a barátoktól a diákok fele-fele; a barátoktól származó információk megbízhatóságának megítélése elenyésző (4,49\%), a család és az iskola hitelességével szemben. A diákok $88,33 \%$-a vett részt középiskolában szexedukációs előadáson. A közvetített családtervezési ismeretek tartalmi részét sem a szakember szakterülete, sem a diákok neme nem befolyásolta $(p>0,05)$. A témával kapcsolatos tudásszint szociodemográfiai faktoroktól független $(p>0,05)$, de a lányok főként a formális csatornán közvetített információkat részesítik előnyben $(p<0,05)$.
\end{abstract}

Következtetések: A fiatalok családtervezési információi elsősorban a fogamzásgátlásra vonatkoztak, ezért a pozitív családtervezési ismertek bővítése szociodemográfiai faktoroktól függetlenül szükséges a formális mellett az informális csatornák használatával is.

Kulcsszavak: szexedukáció; szakemberek szerepe; pozitív családtervezés

\section{Summary:}

Objective: The purpose of our research is to examine the knowledge, information sources and vision of 14-18 years old young people concerning the field of family planning.

Methods: Our quantitative, cross-sectional research was conducted in a secondary school in Veszprém and in Tapolca in 2017. Non-random, convenience sampling was carried out among pupils of full-time secondary education $(n=182)$, who completed our own questionnaire. To analyse data, we used the chi-square test $(p<0.05)$ in Microsoft Excel to determine the correlation between two variables.

Results: The gender distribution of the respondents is nearly the same, with more than half of them planning to have at least two children. Family planning skills have been transmitted to young people from more than one source: $80 \%$ from their family, $50 \%-50 \%$ from the school 
and from friends also, although the reliability of the latter is negligible (4.49\%) compared to the credibility of family and school. $88.33 \%$ of pupils attended sex education sessions during secondary school years. The content of transmitted family planning related knowledge was influenced neither by the specialty of the professional, nor by the gender of pupils $(p>0.05)$. The level of knowledge on the subject is independent of socio-demographic factors ( $p>0.05)$, however girls prefer information transmitted through formal channels mostly $(p<0.05)$.

Conclusion: Young people's family planning information referred primarily to contraception, so the expansion of knowledge on positive family planning is necessary, regardless of socio-demographic factors, using not only formal channels, but informal ones also.

Keywords: sex education; role of specialists; positive family planning

\section{BEVEZETÉS}

A szexuális nevelés felkészíti a fiatalokat a párkapcsolatban adódó nehézségek egy részére, célja, hogy eloszlassa a szexuális bizonytalanságból eredő kétségeket. A hatékony egészségnevelés csökkenti a magas kockázatú szexuális magatartás előfordulását, vagyis a nem kívánt terhességek és a nemi úton terjedő betegségek előfordulásának arányát. Devosa és mtsai egy 2009-2011-es kutatás során megállapították, hogy a fiatal felnőttek 57,6\%-a tartja megbízhatónak az egészségügyi szakemberek, 57,4\%-a a család, 57,0\%-a az internet, valamint 44,1\%-a a barátok, kortársak és $40,9 \%$-a a nyomtatott sajtó által átadott, nemi élettel kapcsolatos információkat. ${ }^{1}$ Számos bizonyíték van arra, hogy a családtervezéssel kapcsolatos tömegkommunikációs üzenetek hatással vannak az egyén fogamzásgátlási, vagyis negatív családtervezési attitűdjére. ${ }^{2}$ Napjainkban a családalapítást tervezőknek számtalan lehetősége van felkészülni szülői szerepükre és a születendő gyermek érkezésére. Az információátadás korán, már gyermekkorban kezdődik és a család mellett az iskola egészségfejlesztő tevékenysége a családi életre történő nevelésben is nagyon fontos. Az iskolai egészségfejlesztésben egyaránt részt vesznek az oktatás-nevelés és az egészségügy területén dolgozó szakemberek. A gyermekek, fiatalok körében megvalósuló kortárs egészségfejlesztő programokra is egyre nagyobb igény mutatkozik. ${ }^{3}$ Az oktatási és nevelési intézményekben fôként a negatív családtervezésre fókuszálnak a családi életre történő felkészítés során, kevésbé koncentrálnak a várandósságra való felkészülésre, a családtervezési tanácsadásra, az egészséges gyermekvárással kapcsolatos életmód kialakítására és a koraterhesség (a terhesség első 12 hete) védelmére. A fiataloknak lehetősége van arra, hogy a pozitív családtervezéssel kapcsolatos kérdéseikkel egészségügyi szakemberekhez forduljanak. Napjainkban a kereskedelmi és közszolgálati televíziós csatornákon futó életmódmagazinok is további információforrást jelenthetnek azoknak, akik tenni szeretnének a várandósság egészséges lefolyásáért.

Egy nő várandósságával kapcsolatos attitúdje jelentős mértékben befolyásolja magatartását és érzelmi állapotát. Családtervezés kapcsán három csoportba sorolhatók a terhességek: tervezett (előre eldöntött a gyermekvárás és annak időpontja is), nem tervezett (a fogantatás nem az előre elhatározott időszakban történik) és nem kívánt várandósság (sem a családalapítás ténye, sem annak időpontja nem tervezett). A nem kívánt terhességek napjainkban is globális problémát jelentenek, hisz egyéni, családon belüli és társadalmi következményekkel járnak. ${ }^{4}$

Devosa a Szegedi Tudományegyetemen két csoportban vizsgálta, hogy a hallgatók melyik fogamzásgátlási módszert tartják megbízhatónak. A legmegbízhatóbbnak mindkét vizsgált csoport a fogamzásgátló tablettát ítélte (88,1\% illetve 93,1\%), ezt követte az óvszer (81,9\% és $81,0 \%)$, majd a méhen belüli hormontartalmú fogamzásgátló eszköz (47,1\% és $48,3 \%)$ és a petevezeték mútéti úton végzett lekötése (46,4\% és 50,0\%). A hallgatók jobban bíznak a hormonális fogamzásgátló tablettában, mint az óvszerben. Ha két említett módszer Pearl-indexét nézzük, amely a fogamzásgátlási módszer biztonságosságát adja meg, akkor látható, hogy a hallgatónak igaza van, azonban érdemes megjegyezni, hogy a kondom a fogamzásgátló tablettákkal szemben védelmet nyújt a szexuális úton terjedő betegségekkel szemben is, ami nem 
elhanyagolható előny, ha valaki nem stabil párkapcsolatban él. ${ }^{5}$

Ugyan a reproduktív korú fiataloknak és felnőtteknek számos lehetőségük van felkészülni a családalapításra, mégis egyre kevesebb gyermek jön világra és jellemzően a szülők is egyre idősebbek az első gyermek születése idején. Ennek egyaránt oka lehet a szülőképes korú nők számának, illetve a gyermekvállalás gyakoriságának csökkenése. A hiányos ismeretek következtében a családtervezés gyakran kimerül a fogamzásgátlás kiiktatásában, azonban az életmódbeli tényezők figyelembevétele háttérbe szorul, így nem valósulhat meg teljesen a tudatos, vagyis pozitív családtervezés. Nagyon fontos, hogy a fiatalok a gyermek születésére, a családdá válás idejére felkészültek legyenek, alkalmassá váljanak a szülői feladatokra és szerepre. ${ }^{6}$

Kozinszky és mtsai szerint az, hogy a nők gyermekvállalása egyre inkább magasabb életkor felé tolódik, egyaránt magyarázható családi, gazdasági, valamint szakmai motivációkkal. Ismert, hogy a 35 év feletti nők várandóssága és szülése során, illetve a gyermekágyi időszakban magasabb arányban fordulnak elő szövődmények, vagyis az idősebb korosztályba tartozó nők terhessége fokozott kockázatot jelent. A veleszületett fejlődési rendellenességek előfordulása is gyakoribb azon anyák gyermekei körében, akik 35 év felett szültek, ezért kiemelt fontosságú minden későbbi életkorban vállalt terhességre kiterjeszteni a magzati kromoszóma-analízist, illetve az ultrahangszürést és a biokémiai szűrővizsgálatokat. Tanulmányuk szerint folyamatosan nőtt a 35 éves kor után először szült nők aránya, akik szignifikánsan magasabb iskolai végzettséggel rendelkeztek. A 35 év felett elsőként gyermeket vállalók magasabb iskolai végzettsége, illetve a tanulmányok befejezésének időbeni kitolódása részben magyarázhatja a késői gyermekvállalást $A z$ idősebb korcsoportban szignifikánsan gyakrabban került sor császármetszésre, azonban a vákuum extrakció és a fogóműtétek számát tekintve lényeges eltérést nem találtak a 35 év alatt és felett szülő nők esetében. A terhesség alatti szövődmények közül a terhességi cukorbetegség és toxémia gyakrabban fordult elő körükben, valamint esetükben kétszer gyakrabban került sor császármetszésre. A 35 év feletti anyák újszülöttjeit gyakrabban kellett intenzív ellátásban részesíteni, vagy neonatális intenzív centrumban kezelni. ${ }^{7}$

A szülés, szülővé válás az egyének és családok kiemelkedően fontos, folyamatosan változó életeseménye, amely generációról generációra új kihívások elé állítja a szakembereket. ${ }^{8}$ Harjánné és mtsai szerint a késői gyermekvállalás hátterében legnagyobb arányban (46\%) párkapcsolati okok állnak (későn találtak párt, rossz partner-kapcsolatban éltek). A második legjelentősebb ok (35\%) a kedvezőtlen anyagi helyzet. A válaszadók 41\%-a vélte úgy, hogy számára komoly anyagi nehézséget okozott a gyermek születése. A még gyermekvállalás előtt állók 13\%-a gondolta úgy, hogy a korai gyermekvállalás akadályozná szabadságában, nem tudná az életet élvezni. ${ }^{9}$

Világszerte évente több mint 80 millió nem kívánt terhesség fordul elő, ami hozzájárul az abortusz, az anyai halálozás és betegségek, valamint a csecsemőhalandóság magas arányához. ${ }^{10}$ Kozinszky és mtsai szerint a magyar népesség gyermekvállalási attitúdje a családok szerkezetét és a kívánt gyerekszámot tekintve is változott. A gyermekvállalási kedvet jelentősen befolyásolja a szexuális gyakorlat, a nemi erkölcs, illetve a vallás. Napjainkban egyre fiatalabb életkorra tehető a nemi élet kezdete a nemi szabadosság és az egyre korábbi biológiai érés miatt, így nemcsak a nem tervezett terhesség elkerülése, hanem a nemi úton terjedő betegségek megelőzése is a fogamzásgátlás célja. A mindkét nemre jellemző karrierorientáltság és a biztos anyagi háttér megteremtésének igénye maga után vonja a gyermekvállalási szokások megváltozását hazánkban is. Az egyre kevesebb gyermek tervezése egyre későbbi életkor felé tolódik el, és ennek következtében nyílik a reprodukciós olló. Mindkét nem esetében egyre hosszabb ideig tart a reprodukcióképes periódus, amely alatt kerülendő mind a nem kívánt és nem tervezett fogamzás, valamint szorgalmazandó a pozitív családtervezés. Különösen fiatal korban magas a tapasztalatlanságból, illetve a különféle fogamzásgátlási módszerek pontatlan alkalmazásából adódó hiba, ami nem kívánt terhességet eredményezhet. Az abortuszok számának csökkentése leghatékonyabban prevencióval, egészségfejlesztéssel érhető el, mely során indokolt a nem kívánt terhességek kockázati tényezőinek 
definiálása és megelőzése. A nem kívánt terhességek elkerülésének módját és a pozitív családtervezés lehetőségét már tinédzser korban, vagy az előtt kell elkezdeni, hogy rögzüljön a fogamzásgátlás helyes gyakorlata. A megfelelő fogamzásgátlási ismeretek átadása a fiatalok számára a legfontosabb, hiszen rendszertelen nemi életük miatt még bizonytalan fogamzásgátlási attitűddel rendelkeznek. ${ }^{11}$

Vizsgálatunk célja az volt, hogy felmérjük a Veszprém megyei, 14-18 éves fiatalok jövőképét és életcéljait a családtervezést illetően: milyen párkapcsolati formában, hány éves korukban, mennyi gyermeket kívánnak vállalni.

A gyermekvállalással kapcsolatban elsősorban azt szeretnénk bemutatni, hogy oktatási intézményenként milyen forrásból származik a kutatásban résztvevő fiatalok tudása, illetve mennyire hatékony az egészségügyi szakemberek információátadása. Fontos, hogy a fiatalok számára hiteles szakember múködjön közre az ismeretek átadásában. Hazánkban a megkérdezett tinédzserek fele úgy érzi, nem elég hatékony a szexuális felvilágosítás. ${ }^{12}$ Mivel a kutatást két különböző típusú középfokú oktatási intézményben (gimnázium és szakgimnázium) folytattuk, arra is választ kerestünk, hogy iskolatípus szerint van-e különbség a fiatalok ismereteiben.

\section{MÓDSZERTAN}

Jelen vizsgálat kvantitatív és keresztmetszeti. A kutatást két Veszprém megyei, középfokú oktatási intézményben folytattuk: a veszprémi Vetési Albert Gimnáziumban, illetve a tapolcai Széchenyi István Baptista Középiskolában, szakgimnáziumi tanulók között. A kérdőívek kitöltésére 2017. áprilisában került sor. A kérdőíveket 202 fő, 14-18 év közötti, vagyis 9-12. évfolyamos tanuló töltötte ki, melyből tisztítás után 182 fő került be a végleges mintába. A saját szerkesztésű kérdőíves vizsgálatunk összesen 31 kérdést tartalmazott, melynek fő kérdéscsoportjai az alábbiak voltak: szociodemográfiai adatok (nem, életkor, szülők iskolázottsága és családi állapota), életmód (fizikai aktivitás, egészséges táplálkozás, várandósság alatt szükséges életmódváltoztatás), jövőkép, életcélok (lehetséges életcé- lok rangsorolása, melyik életcél kapcsán érzi úgy a válaszadó, hogy elengedhetetlen a harmonikus élethez), családalapítással kapcsolatos tervek (milyen életkorban és társas kapcsolatban vállalkozna családalapításra, hány gyermeket tervez), és az ezzel kapcsolatos oktatás (pozitív családtervezés fogalmának ismerete, szexuális felvilágosítás, ki szolgáltatta az információt, hatékony volt-e az információszolgáltatás). Két változó összefüggéseinek megállapítására alkalmazott statisztikai módszer a khí-négyezet próba volt, továbbá a leíró statisztika keretein belül átlag- és gyakoriságszámítást végeztünk, az eredményeket 95\%-os megbízhatósági tartomány mellett $p<0,05$ esetén tekintettük szignifikánsnak. ${ }^{13}$

\section{EREDMÉNYEK}

\subsection{Szociodemográfiai adatok}

Szociodemográfiai jellemzők tekintetében a kérdőívet kitöltő fiatalok nemére, életkorára, lakhelyére, valamint jelenlegi iskolatípusukra kérdeztünk rá. A teljes minta elemszáma 182 fő, a kitöltők 51,10\%a (93 fő) nő, 48,90\%-uk (79 fő) pedig férfi, tehát közel azonos arányban volt jelen a két nem a válaszadók között. Életkor tekintetében a vizsgálat idején mindössze egy 14 éves tanuló volt, ő a válaszadók 0,55\%-át tette ki. A legnagyobb létszámú csoportot a 16 éves diákok alkották 54 fővel, mely a kutatásban résztvevők 29,67\%-a, a 17. életévüket betöltött tanulók a vizsgált populáció 28,02\%-át (51 fő) alkották, a kérdőív kitöltésekor pedig 15 éves volt a diákok 21,43\%-a (39 fő), valamint 18 éves a kitöltők 20,33\%-a (37 fő). Lakóhely szerint a válaszadók 58,33\%-a (107 fő) városban élt, míg 41,67\%-a (75 fő) falusi volt. Iskolatípus szerinti megosztottságban közel azonos arányban voltak jelen a fiatalok: gimnáziumba járt a kitöltők 55,25\%-a, szakgimnáziumba pedig a tanulók 44,75\%-a.

\subsection{Továbbtanulási szándékok felmérése, életcélok}

A kitöltők jelentős többsége, 84,62\%-a (154 fő) kíván továbbtanulni. A továbbtanulást tervezők 
79,08\%-a (122 fő) felsőfokú oktatásban szeretne részesülni, míg 20,92\% (32 fő) szakma elsajátítását tervezi. A tervezett főiskolai és egyetemi tanulmányok miatt várhatóan magas lesz azoknak a tanulóknak az aránya, akik viszonylag későbbi életkorban válnak gazdaságilag aktívvá. A tanulmányok várható befejezését illetően három csoportot különböztethetünk meg egyéni válaszok alapján: 20-22 év (15,58\%), 23-25 év (62,99\%) és 26 év (21,43\%) vagy annál később. [1. ábra] A legnagyobb csoportot azok a tanulók alkották 97 fővel, akik 23 és 25 éves kor között szeretnék befejezni tanulmányaikat.

1. ábra: A fiatalok továbbtanulási szándéka és a tanulmányok befejezését jelölő életkor közötti összefüggések (n=153)

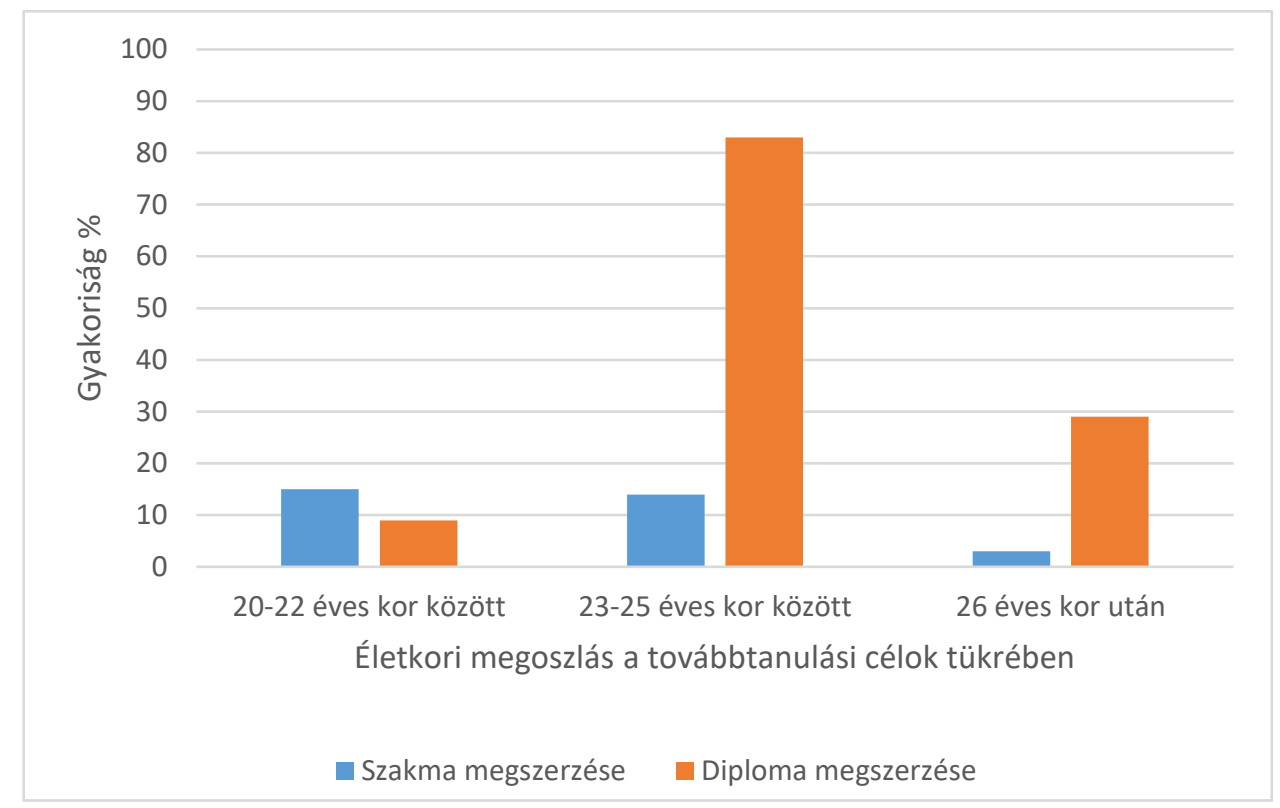

Forrás: saját szerkesztés

Szerettünk volna választ kapni arra, hogy a 14-18 éves fiatalok jelenleg mit tartanak fontosnak és kevésbé lényegesnek életükben. Ehhez egy általunk összeállított lista alapján kellett rangsorolni 5 lehetséges életcélt úgy, hogy az 1 a legfontosabb, míg az 5 a legkevésbé lényeges jövőbeni életterület. $\mathrm{Az}$ öt rangsorolandó életcél az alábbiak voltak: karrier, kapcsolatépítés, családalapítás (gyermekvállalás), társadalmi státusz emelése, pénzszerzés. A fiatalok az összes lehetőség közül legkevésbé fontosnak a magas társadalmi státusz kialakítását tartották: első helyen mindössze a válaszadók 1,68\%-a, tehát 3 fő jelölte meg, ellenben ötödikként, vagyis a legkevésbé fontos életcélnak a kitöltók 58,66\%-a (105 fó). A fiatalok legnagyobb hányada (35,96\%-a, 64 fö) szerint a kapcsolatépítés a legfontosabb, ami szükséges a boldog, teljes értékú élethez, mindössze 1 diák (0,56\%) fontossági sorrendjében került ez az utolsó helyre. A második legnépszerúbb életcélként a karrierépítést jelölte meg a kitöltők 25,28\%-a (45 fó). A rangsor közepén végzett a családalapítás, gyermekvállalás, melyet a válaszadók 24,58\%-a (44 fő) tartott a legfontosabb életcélnak. Az anyagi források gyarapítása a lista negyedik helyén végzett (11,73\%, 21 fő), a megélhetést a diákok legtöbbje a saját preferencialistáján a negyedik helyre sorolta (29,61\%, 53 fő).

\subsection{A válaszadók gyermekvállalással kapcsolatos attitűdje}

A következő kérdéscsoport, ami négy kérdést tartalmazott, a várandósság alatti életmóddal, a családalapítási életkorral és a tervezett gyermekszámmal kapcsolatos attitűdre vonatkozott, valamint azt vizsgáltuk, hogy a diákoknak mennyire fontos a boldog élethez a szülővé válás. Az első kérdés arra vonatkozott, hogy a válaszadó szerint 
szükséges-e gyermekvállalás előtt, illetve annak során a szülőknek változtatni addigi életmódjukon. A válaszlehetőségek az alábbiak voltak: mindkét szülőnek, csak az anyának, csak az apának, illetve egyik szülőnek sincs szüksége életmód-változtatásra. A diákok jelentős többsége, 90,66\%-a (165 fő) gondolta úgy, hogy mindkét szülőnek változtatni kell életmódján a család bővítésekor. 3,30\% (6 fő) szerint csak az anyának kell változtatnia életmódján, míg 0,55\% (1 fő) úgy véli, erre az apának van szüksége. A diákok 5,49\%-a (10 fő) azon a véleményen van, hogy a leendő szülők egyikének sem kell életvitelén változtatnia a gyermekvárás ideje alatt. Ezután arról kérdeztük a tanulókat, hogy hajlandóak lennének-e saját életmódjukon változtatni gyermekvállalás esetén. Három válaszadási lehetőséget kínáltunk fel, mely szerint a kitöltő mindenképp életmódot váltana, vagy változtatna életmódján, de nem radikális mértékben, illetve azon nem lenne hajlandó változtatni. Ezen kérdésre a „nem” választ adóktól megkérdeztük, hogy mi lenne ennek az oka, melyre egyéni választ adhattak. Ezeket összesítve három ok körvonalazódott. Az életmódváltást elutasító 10 fő 50\%-a saját bevallása szerint jelenleg is olyan életmódot él, ami nem lenne káros a magzatára nézve, 30\% (3 fő) nem szeretné, ha a gyermekvállalás befolyásolná élete más területét, 20\% (2 fö) pedig még nem biztos benne, hogy szeretne családot alapítani, így ez a kérdés nem foglalkoztatja. Az „,igennel” válaszolóknak is további kérdést tettünk fel, mely arra vonatkozott, hogy az életük mely területén eszközölnék a változtatásokat. Válaszlehetőségként a káros szenvedély elhagyását, fokozott fizikai aktivitást, egészségesebb táplálkozást és a harmonikus, nyugodt napirendet adtuk meg, valamint az "egyéb” rubrikát arra az esetre, ha a kitöltőnek más elképzelése van. Ezt a lehetőséget 5 fő (2,98\%) választotta, de véleményüket nem fejtették ki. A kitöltők nagy része, 79,17\%a (133 fó) a kiegyensúlyozott, harmonikus mindennapokat emelte ki, 41,07\%-a (69 fö) lemondana káros szenvedélyéről, 43,45\%-a (73 fő) változtatna étkezési szokásain és 22,62\%-a (38 fő) sportolna többet.

A diákoknak egy 1-5-ig terjedő Likert-skálán kellett jelölniük azt, hogy számukra mennyire fontos a teljes értékú élethez a szülővé válás. A skálán az 1 azt jelenti, hogy egyáltalán nem fontos, míg az 5-ös érték esetén mindenképp fontosnak tartja a gyermekvállalást. A boldog élethez feltétlenül szükségesnek tartja a szülővé válást a tanulók 33,16\%-a (60 fő). Legnagyobb hányaduk, 41,99\%-uk (76 fő) a négyes értéket jelölte meg a skálán, 16,08\%-uk (29 fő) közepesen, tehát részben tartja fontosnak a családalapítást a saját életében. Csupán 4,88\% (9 fö) az, aki a kettes értéket jelölte meg, valamint 3,89\% (7 fő) gondolja úgy, hogy élete gyermekvállalás nélkül is teljes értékű lenne.

Arról is érdeklődtünk, hogy a tanulók hány gyermeket szeretnének vállalni. A diákok 58,53\%-a (106 fő) két gyermeket tervez. Nagycsaládos életet a diákok 11,54\%-a (21 fő) szeretne élni, azaz három vagy annál több gyermeket szeretne, további 13,19\% (24 fő) egy gyermek vállalását tartja ideálisnak. 4,10\% (8 fő) jelenlegi elképzelés alapján nem kíván a későbbiekben családot alapítani, és a válaszadók 12,64\%-a (23 fő) még nem rendelkezik tervekkel ezen a téren.

A megkérdezett tanulóknak arra is választ kellett adniuk, hogy milyen kapcsolati formában képzelik el a gyermekvállalást. Négy lehetőség közül lehetett választani: házasságban, vagy élettársi kapcsolatban képzelik el a családalapítást, egyedülállóként is hajlandóak lennének a gyermekvállalásra, illetve egyéni válasz esetén szintén rendelkezésre állt az „egyéb" rubrika, melyet a tanulók 0,55\%-a (1 fő) jelölt meg, de saját elképzelését nem fogalmazta meg. A jelentős többség, 83,42\% (150 fő) a házasság intézményén belül tervez gyermekvállalást. Élettársi kapcsolatban 14,93\% (29 fö) szeretne családot alapítani, és csupán 1,10\%-ot ( 2 fő) nem tartana vissza a szülővé válástól az egyedülállóság.

A következő kérdések arra vonatkoztak, hogy a kitöltők szerint mely életkor a legmegfelelőbb családalapításra, valamint hány évesen szándékoznak gyermeket vállalni. Mindkét esetben öt lehetőség közül választhattak a diákok: 20 éves kor előtt, 21-25, 26-30, 31-35 évesen vagy 36 év és efelett. Gyermekvárásra ideális életkornak a tanulók többsége a 26-30 éves kor közötti időszakot tartja, ők a kitöltők 62,48\%-át teszik ki (113 fő). 29,81\% (54 fő) véleménye alapján ez az időszak 21-25 éves kor közötti jön el, 5,50\% (10 fő) pedig a 31-35 éves kort tartja optimálisnak. A diákok közül 5 fő (2,21\%) jelölte a 20 év alatti életkort. A kitöltők közül senki sem gondolta úgy, hogy 36 évesen vagy annál idősebben kellene gyermeket vállalni. A diákok saját életükben is hasonló időszakra tervezik a 
családalapítást: 63,48\% (113 fő) gondolja úgy, hogy első gyermekét 26-30 évesen szeretné vállalni, 25,28\% (45 fő) 21-25 évesen, 9,55\% (17 fő) 31-35 évesen és 1,12\% (2 fő) 36 évesen vagy annál idősebben.

\subsection{Családtervezéssel kapcsolatos információforrások}

Nemek szerint vizsgáltuk a fiatalok információszerzési forrásait. A 182 kitöltő 51,10\%-a nő, mely 93 főt takar. Közülük 4,30\% (4 fö) csak formális kereteken belül kapott ismereteket a családtervezésről, 58,07\% (54 fó) a felvilágosító órákon és egyéb, intézményi kereteken kívüli forrásokból egyaránt kapott információt, valamint 37,63\% (35 fó) csak oktatáson kívül szerzett ismereteket. Fiúk tekintetében a részvételi arány 48,90\% (89 fő) volt az iskolai felvilágosító órákon, 2,25\%-uk (2 fő) csak informális forrásból szerzett tudást a gyermekvállalással kapcsolatban, 34,83\% (31 fő) mind iskolai, mind egyéb forrásból kapott már ismeretet, 62,92\%-uk (56 fő) pedig kizárólag oktatáson kívül szerezte meg tudását. [2. ábra] Összességében elmondható, hogy összefüggés van a nem és a pozitív családtervezéssel kapcsolatos információszerzés módja között $(p=0,003 ; \chi 2=11,654)$.

2. ábra: A válaszadó nem szerinti megoszlása az információforrások tekintetében (n=182)

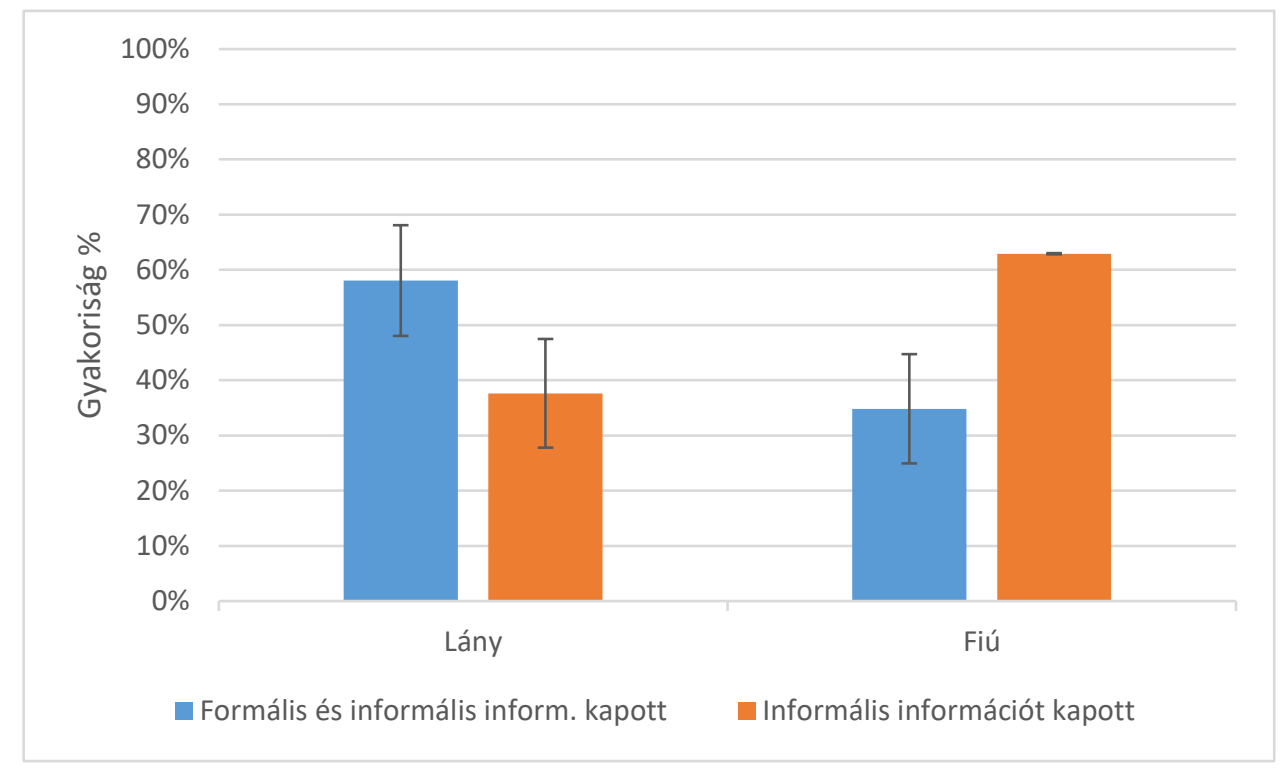

Forrás: saját szerkesztés

Ezután arra kellett választ adni a diákoknak, hogy az információforrásaik közül melyik volt számukra a leghitelesebb. Erre a kérdésre a kitöltók közül csak 178 fő adott választ. 63,48\% (113 fő) a családi kapcsolatok révén kapott információkat tartja a legmegbízhatóbbnak, míg 26,98\% (48 fő) a felvilágosító órákon szerzett hiteles ismereteket. Hitelesnek csak 3,93\% (7 fö) ítéli meg a kortársaktól kapott információkat, valamint a média eszközei felé is hasonló arányban mutatkozik bizalom a fiatalok részéről: 4,49\% (8 fő) tartja hitelesnek az interneten közvetített ismereteket, és csupán 1,12\% (2 fő) bízik az oktató jellegú könyvekben, magazinokban.
Megkérdeztük a tanulókat, hogy oktatási kereteken belül részt vettek-e szexuális felvilágosító órán. A válaszadók 88,33\%-a (159 fó) volt már iskolai felvilágosító órán, akik közül legtöbben (61,53\%, azaz 112 fő) védőnők által tartott előadáson vettek részt. A védőnők az összes felsorolt témáról jelentős arányban tartottak előadást, melyeken a diákok 88,39\%-a hallott a negatív családtervezésről, vagyis a fogamzásgátlásról, de 63,39\%-uk (71 fö) a koraterhesség védelméről is kapott információkat. A résztvevők több, mint fele $(54,46 \%$, azaz 61 fő) kapott védőnői segítséget ahhoz, hogy megismerje, miként készülhet tudatosan a várandósságra, illetve hogyan 
élhet egészségesen a gyermekvárás időszaka alatt is. A tanulók 22,73\%-a (15 fő) a családtervezési konzultációról is tanulhatott új dolgokat. 66 diák $(36,26 \%)$ iskolaorvos által tartott ismeretterjesztő előadáson vett rész, melyen 84,85\%-uk (56 fő) kapott információt a fogamzásgátlás módszereiről, 40,91\%-uk (27 fő) tájékozódhatott a várandósság megtervezéséről, valamint hasonló arányban (39,39\%, 26 fő) jutottak új ismeretekhez a terhesség alatti egészséges életmódról. A családtervezési konzultáció lehetőségéről a kitöltők 22,73\%-a (15 fő) hallott az iskolaorvostól. Pedagógusok 50 fő (a diákok 27,47\%-a) számára nyújtottak információt a családtervezésről. Az általuk tartott előadások keretében túlnyomórészt a negatív családtervezés volt a vezető téma (78\%, 39 fó). Kevesebbszer (42\%, 21 fő) került szóba a koraterhesség védelme, illetve ezzel közel azonos arányban szerezhettek új ismereteket a tanulók a gyermekvárás alatti egészséges életmódról (30\%, 15 fő), a terhességre felkészülésről (26\%, 13 fő) és a családtervezési konzultáció lehetőségeiről (22\%, 11 fő).

\subsection{A pozitív családtervezés fogalmának ismerete, egészséges gyermekvárással kapcsolatos életmód}

Érdeklődtünk, hogy a diákok ismerik-e a pozitív családtervezés fogalmát. A válaszadók 55,49\%-a (101 fő) volt tisztában a fogalom jelentésével. Majd arra voltunk kíváncsiak, hogy mi a véleményük arról a felvetésről, hogy a várandósságot érdemes előre megtervezni. Három válaszlehetőség közül választhattak a diákok: mindenképp szükséges a gyermekvállalás megtervezése, avagy fontos előre tervezni, de anélkül is fel lehet készülni a gyermekáldásra, felnevelésre, illetve egyáltalán nem fontos az előre kalkulálás. A kitöltók jelentős többsége, 69,23\%-a (126 fő) úgy véli, hogy rendkívül fontos már a fogantatás előtt felkészülni a várandósságra, 26,37\%-uk (48 fő) szerint ez a tervezési folyamat nem szükségszerü, de hasznos és 4,40\%-uk (8 fő) gondolja csak úgy, hogy nem lényeges a gyermekvárás megtervezése. [3. ábra]

3. ábra: Az egészséges gyermekvárással kapcsolatos információmennyiség és a szociodemográfiai tényezők közti összefüggés ( $n=182$ )

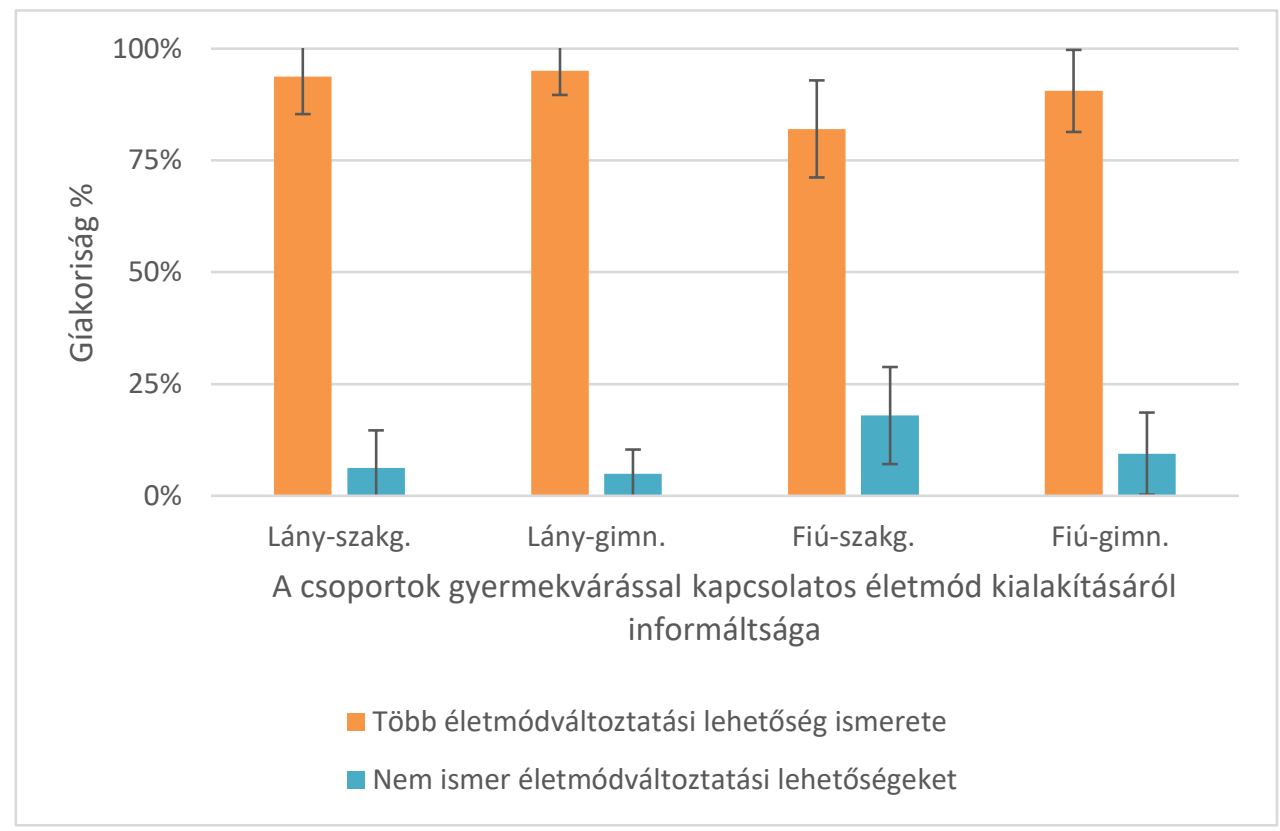

Forrás: saját szerkesztés

Kíváncsiak voltunk arra, hogy a fiatalok szerint a várandósság ideje alatt mit lehet tenni a születendő gyermek egészségéért. A kérdésre 163 fő adott választ. Miután minden kitöltő saját szavaival fogalmazta meg a válaszát, azokat rendszereztük és végül 8 kategóriába soroltuk őket. Általánosságban 
véve, a kitöltők nagyobb hányada, egészen pontosan 83,52\%-a (152 fő) életmód-változtatást javasolna, mely alatt elsősorban a káros szenvedélyek elhagyását és az egészségesebb táplálkozást értették. 18,68\%-uk (34 fő) ösztönözné a terhes nőt könnyű fizikai aktivitás végzésére (pl. kismama torna), 15,93\%-uk (29 fö) szerint az egészséges gyermekváráshoz elengedhetetlen a stresszmentes, harmonikus párkapcsolat. A terhesvitaminok jótékony hatását a kitöltők 11,54\%-a (21 fö) ismeri, további 10,44\%-uk (19 fő) gondolja úgy, hogy fontos az egészségügyi szakemberek javaslatait betartani. 6,44\% (11 fó) véleménye szerint lényeges, hogy gyermekbarát környezetet biztosítsanak az újszülöttnek és 4,95\% (9 fö) úgy véli, fontos a pszichés támogatás a család és a barátok részéről a születendő gyermek egészséges fejlődéséhez.

\section{MEGBESZÉLÉS, KÖVETKEZTETÉSEK}

A családtervezés kapcsán fontosnak bizonyulnak az egészségügyi szakemberek tanácsai. Fontos, hogy a családi életre és a szülői szerepre való felkészítésre ne csak a várandósok körében kerüljön sor, hanem a reproduktív korú fiatalok számára is elérhetőek legyenek ezek az információk, férfiak és nők számára egyaránt, hiszen a családtervezés nemcsak a nők felelőssége. ${ }^{14}$ Összességében elmondható, hogy az általunk megkérdezett fiatalok arról számoltak be, hogy a vezető téma a negatív családtervezés volt. A legtöbb tanuló védőnő által tartott órán vett részt (112 fő, 61,53\%), a legkevesebb foglalkozást pedig a szülésznők (9 fő, 4,95\%) tartották. Az eredmények alapján nincs szignifikáns összefüggés $(p>0,05)$ az edukáció során kapott ismeretmennyiség és az előadó szakterülete között (oktatás, egészségügy). Védőnők által tartott órán a résztvevők 88,39\%-a (99 fö) kapott információt a fogamzásgátlásról, szülész-nőgyógyász szakorvosok előadásain a mintában lévők 79,41\%-a (27 fő). Összességében a negatív családtervezés módszereiről a felvilágosító órákon jelentős mennyiségú új ismeretet szerzett a tanulók kétharmada. Egy 2013as, szintén hazai középiskolások körében végzett vizsgálat eredményei szerint az iskolai edukáció a vártnál alacsonyabb mértékben, de tendenciaszerúen befolyásolta a fogamzásgátlási ismereteket ( $p>0,05) .{ }^{15}$ Tanulmányunkban azt tapasztaltuk, szexuális felvilágosítást adó foglalkozáson a tanulók 88,33\%-a (159 fő) vett részt. Közülük csupán 64 fő 40,25\%) kapott tájékoztatást a pozitív családtervezés lehetőségéről. Nemek tekintetében közel azonos arányban vannak mind az informált, mind az ismeretekkel nem rendelkező tanulók tehát szignifikáns összefüggés nem mutatható ki a diákok neme, és az informáltság tekintetében ( $p>0,05)$.

A megelőző ismeretekhez azonban nemcsak az egészség védelme és fejlesztése, hanem az egészségügyi szolgáltatások megfelelő használata, az orvoshoz fordulás kultúrája, illetve a javasolt szűrővizsgálatokon való részvétel is hozzátartoznak.

A várandósság alatti káros szenvedélyek - mint az alkoholfogyasztás, vagy a dohányzás -, a negatív szülészeti történések (alulfejlettség, koraszülés, méhen belüli elhalás) egyik fő generátorai. Korábbi tanulmányok szerint az anyai egészségkárosító magatartás gyökere leginkább intraperszonális, vagyis egyéni, amit elsősorban a várandós szociodemográfiai státusza határoz meg. Azonban frissebb kutatások arra a következtetésre jutottak, hogy nemcsak az egyéni tényezők, hanem a környezet is hatással van az anyai életmódra, elsősorban a család és a barátok által nyújtott információk, az egészségügyi szakemberektől kapott tájékoztatás, de a média által közölt ismeret is befolyásoló hatású. ${ }^{16}$

Számos hazai kutatás is foglalkozik a szervezett nőgyógyászati szűrésektől való távolmaradás okainak feltárásával, 17,18,19,20,21 az oki tényezőkre és a megelőzésre vonatkozó ismeretek felmérésével ${ }^{22,23}$ és szüréssel, valamint a humán papillómavírus (HPV) okozta fertőzés elleni oltással kapcsolatos attitűd vizsgálatával. A HPV nemi úton terjedve méhnyakrákot okozhat, azonban a fertőzés védőoltással megelőzhető, valamint a vakcinát nem kapott nők esetében a rákmegelőző állapot szüréssel felismerhető. $^{24,25}$ Ugyancsak nagyon fontos felhívni a figyelmet a mellrák szürésének fontosságára, illetve a lányoknak megtanítani az emlő önvizsgálatát. Tudatosítani kell a családtervezéssel foglalkozó előadások során is a nőgyógyászati szűrővizsgálat menetét, lehetséges hasznát, korlátait, valamint a távolmaradással járó kockázatot. Fiúk esetében ugyanilyen fontos a herék önvizsgálatának megtanítása és a vastagbélrák szúrésének ismertetése, valamint megadni nekik az andrológiai és urológiai szakrendelések elérhetőségeit. Ugyan ingyenes HPV oltásban jelenleg az általános iskola 7. osztályában 
tanuló lányok részesülhetnek, a serdülő fiúk számára is ajánlható a vakcina.

A médiában megjelenő szexualitással kapcsolatos üzenetek gyakran távol állnak a valóságtól és hamis képet alakíthatnak ki a fiatalokban. ${ }^{26} \mathrm{~A}$ válaszadók 41,90\%-a (76 fő) a médiából - elsősorban a világhálóról és a televízióból - is gyűjt információkat, de az onnan származó ismereteket fenntartásokkal kezelik, mindössze a diákok 4,49\%-a (8 fő) tartja azt megbízható forrásnak. A média által közvetített információ megbízhatósága kutatásunkban teljesen eltérő mértékű, mint Devosa és mtsai kutatásában, ahol a válaszadók 57,0\%-a (269 fó) tartotta megbízhatónak az internet által szolgáltatott információt a fogamzásgátlásra és a nemi életre vonatkozóan. ${ }^{1}$ Az eltérés okát egyaránt kereshetjük a megkérdezettek eltérő életkorában és iskolázottságában, valamint kutatásunk jóval kisebb elemszámában. A fiatalok kétharmada a kutatás idején úgy gondolta, hogy a gyermekvállalás szempontjából a 26-30 éves időszak a legideálisabb. A tanulók $63,48 \%$-a is ebben az időszakban tervez családalapítást. A fiatalok mintegy negyede azonban ennél korábban, 21-25 évesen szeretné első gyermekének világra jöttét. A Központi Statisztikai Hivatal 2017-es adatai szerint a Veszprém megyében született gyermekek legnagyobb aránya (35\%-a) az anya 25-29 éves korában jön a világra, vagyis a felmérésünkben a diákok által leginkább preferált családalapítási időszak megegyezik a jelenlegi megyei trenddel. ${ }^{27}$ Hazánkban jelenleg is a legelterjedtebb családmodell a kétgyermekes. ${ }^{28}$ A tinédzserként szőtt tervek az életkor előrehaladtával sokat módosulhatnak. Spéder és mtsai kutatása alapján leggyakrabban a két gyermeket vállalni szándékozó fiatalok tervei valósulnak meg. ${ }^{29}$ Ők felmérésünkben a minta 58,24\%-át (106 fő) teszik ki, vagyis az ő családalapításra vonatkozó céljaik várhatóan megvalósulnak. A korábban tervezett gyermekszámhoz képest kevesebb gyermeket vállalnak végül azok, akik élettársi kapcsolatban élnek és nem házasságban. ${ }^{29}$ Kutatásunkban a diákok 82,42\%-a házastársi kapcsolaton belül szándékozik gyermeket vállalni, és csak 15,93\% lenne hajlandó élettársi viszonyban családot alapítani. Mivel a tanulók döntő hányada házasságon belül kíván gyermeket vállalni, várható, hogy a diákok által tervezett gyermekek világra jönnek.

Mivel felmérésünk kisebb mintán történt, ezért messzemenő következtetéseket nem vonunk le eredményeinkből, azokat inkább részeredménynek tekintjük, amelyek viszont sejtetik a téma további kutatásának fontosságát. Tanulmányunk a fiatalok családtervezéssel kapcsolatos jövőképe mellett a szexuális felvilágosítással való elégedettségüket is mérte. Úgy gondoljuk, hogy érdemes lenne további vizsgálatokat folytatni a szexedukáció területén, melyek eredményei hozzájárulhatnak az oktatás hatékonyságának növeléséhez. Szükséges lenne szervezett, országos programmá emelni a pozitív családtervezési ismeretek terjesztését, melynek keretében a kortárs segítőkre támaszkodva, biztosítani lehetne a bizalmas hangvételt, a személyes megszólítást a hiteles információk átadása mellett. ${ }^{30} \mathrm{Az}$ edukáció diákok igényeihez való igazításában jelen vizsgálat kutatási anyaga segítség lehet a jövőben.

\section{HIVATKOZÁSOK}

\footnotetext{
${ }^{1}$ Devosa I, Kozinszky Z, Vanya M és mtsai. Szegedi egyetemi hallgatók ismeretei a megbízható fogamzásgátlásról és a szexuális úton terjedő betegségekről. Orv. Hetil. 2016; 157 (14): 539-546. doi: 10.1556/650.2015.30356

${ }^{2}$ Gupta N, Katende C, Bessinger R. Associations of Mass Media Exposure with Family Planning Attitudes and Practices in Uganda. Stud Fam Plan. 2003; 34(1): 19-31. doi: 10.1111/j.1728-4465.2003.00019.x

${ }^{3}$ Lukács JÁ, Mészárosné Darvay S, Soósné Kiss Zs és mtsai. Kortárs egészségfejlesztési programok gyermekek és fiatalok körében a hazai és a nemzetközi szakirodalom tükrében - Szisztematikus áttekintés. Egészségfejlesztés. $2018 ; 59$ (1): 6-24. doi: 10.24365/ef.v59i1.215

${ }^{4}$ Özkan I, Mete S. Pregnancy planning and antenatal health behaviour findings from one maternity unit in Turkey. Midwifery, 2010;26 (3): 338-347. doi: 10.1016/j.midw.2008.07.005

${ }^{5}$ Devosa I. A Kortárssegítés hatékonyságának vizsgálata a reproduktív egészségfejlesztő munkában, és az eredmények alapján kialakított Ariadné többgenerációs egészségfejlesztő program ismertetése, PhD értekezés tézisei, Szegedi Tudományegyetem, Bölcsészettudományi Kar Neveléstudományi Doktori Iskola. Szeged, 2017. doktori.bibl.u-szeged.hu/9781/3/Devosa Ivan PhD tezisfuzet HUN.pdf (Elérve: 2019. 02. 25.)
} 
${ }^{6}$ Jósvai Z, Soósné Kiss Z. Első gyermeküket váró szülők szülői szerepre való felkészültsége, a felkészítő foglalkozások megítélése, a gyermekáldás és a káros szenvedélyek jelenléte gyermekbiztos óvintézkedések alapján.

Egészségfejlesztés. 2014;55(3): 2-10.

${ }^{7}$ Kozinszky Z., Orvos H., Zádori J és mtsai. 35 éven felüli először szülő nők terhessége és újszülöttjeinek neonatológiai jellemzői. Magyar Nőorvosok Lapja. 2002; 65 (4): 249-254. publicatio.bibl.u-szeged.hu/13023/7/13023.pdf (Elérve: 2019. 02. 25.)

${ }^{8}$ Soósné Kiss Zs, Péter M, Lipienné Krémer I. Családok szülésre és szülőségre való felkészítése - változások az előző generációhoz képest. Egészségfejlesztés. 2018;59 (2): 55-62. doi: 10.24365/ef.v59i5.329

${ }^{9}$ Harjánné Brantmüller A, Törkey D, Gelencsér E és mtsai. Késői gyermekvállalás. Egészség Akadémia. 2014;5 (3): 131-140. etk.pte.hu/public/upload/files/EgeszsegAkademia/2014 V 3/3. Harjanne.pdf (Elérve: 2019. 02. 20.)

${ }^{10}$ Mwaikambo L., S. Speizer, Schurmann A. What Works in Family Planning Interventions: A Systematic Review.

Stud Fam Plan. 2011; 42(2): 67-82. www.ncbi.nlm.nih.gov/pmc/articles/PMC3761067/(Elérve: 2019. 02. 25.)

${ }^{11}$ Kozinszky Z., Csatordai S., Csepiné Szűcs G. A művi terhességmegszakítások számának elemzése hazánkban. Magyar Nőorvosok Lapja. 2006;69 (6): 501-514. www.doki.net/tarsasag/noorvos/upload/noorvos/magazine/kozinszky.pdf

(Elérve: 2019. 02. 18.)

12 Erős E, Hajós A. Szexuális nevelés ma: jó irányba haladunk? Gyermekgyógyászat.2017;68.(1): 36-40.

13 Pakai A, Kívés Zs. Kutatásról ápolóknak 2. rész: Mintavétel és adatgyújtési módszerek az egészségtudományi kutatásokban. Nővér. 2013; 26: 20-43.

${ }^{14}$ Bodin M., Stern J.,Folkmarson K., Tydén L. Coherence of pregnancy planning within couples expecting a child. Midwifery. 2015; 31.(10): 973-978. doi: 10.1016/j.midw.2015.06.009

15 Jäger A, Pusztafalvi H. Szexuális magatartás vizsgálat a középiskolások körében. Egészség Akadémia. 2013; 4: 50-58. etk.pte.hu/public/upload/files/EgeszsegAkademia/2013 IV 1/7 JagerAnett.pdf (Elérve: 2019. 02. 24.)

${ }^{16}$ Ghorashi H., Schölmerich L. N., Denktas V. Caught in the middle? How women deal with conflicting pregnancy- advice from health professionals and their social networks. Midwifery. 2016; 32.(4):62-69. doi: 10.1016/j.midw.2016.02.012

17 Pakai A, Dér A, Kriszbacher I és mtsai. Why don't Hungarian women take part in organized cervical screenings? New Med. 2014;14 (1): 25-28. www.czytelniamedyczna.pl/3336, why-dont-hungarian-women-take-part-in-organized-cervical-screening.html (Elérve: 2019. 02. 20.)

${ }^{18}$ Karamánné Pakai A, Németh K, Kriszbacher, I és mtsai. A szervezett méhnyakrák-szürés távolmaradás okainak vizsgálata a Nyugat-dunántúli régióban élő nők körében. Magyar Epidemiológia. 2009;6 (1): 9-20.

19 Pakai A, Brantmüller É, Vajda R et al. Reasons for non-appearance on organized cervical screening in Hungary. PTSE. 2017; 11(2):142-154. doi: 10.1515/ptse-2016-0015

${ }^{20}$ Pakai A, Oláh A, Farkasné Buzánczky G et al. Attitude examination related to breast cancer among women in Bács-Kiskun county, Hungary. PTSE. 2017; 11 (3) 223-232. doi: 10.1515/ptse-2016-00

${ }^{21}$ Karamánné Pakai A, Németh $\mathrm{K}$, Dér A és mtsai. A szervezett méhnyakrák-szűrés távolmaradás okainak vizsgálata magyar nők körében. Bulletin of Medical Science/Orvostudományi Értesítő. 2008;81: 271-275. www.orvtudert.ro/images/PDF/2008 4/2008 4 12.pdf (Elérve: 2019. 02. 15.)

22 Pakai A, Novákné Szabó Sz, Karácsony I, Vajda R. Roma nők ismereteinek felmérése védőnői körzetben a méhnyakrák és kockázati tényezőivel kapcsolatban. Romológia. 2018;6 (16-17) :76-97.

epa.oszk.hu/02400/02473/00014/pdf/EPA02473 romologia 201803 076-097.pdf (Elérve: 2019. 02. 15.)

${ }^{23}$ Bogdánné Basa E, Vajda R, Váradyné Horváth Á és mtsai. Méhnyakrákkal kapcsolatos ismeretszint roma nők körében. Nővér. 2017; 30 (2) 31-39.

${ }^{24}$ Millei K, Vajda R, Kívés Zs és mtsai. HPV-fertőzéssel kapcsolatos ismeretek vizsgálata édesanyák és leányaik körében. Egészségfejlesztés. 2015; 56 (3): 9-16.

${ }^{25}$ Vajda R, Kívés Zs, Éliás Zs és mtsai. A humán papillómavírussal (HPV) kapcsolatos attitűdvizsgálat. Magyar Nőorvosok Lapja. 2014;77(3): 18-25.

${ }^{26}$ Erős E, Supák D. Szexuális felvilágosítás: eleget teszünk-e a kamaszokért? Gyermekgyógyászat. 2011; 62: 23-26.

${ }^{27}$ Központi Statisztikai Hivatal. Magyarország, 2017. Központi Statisztikai Hivatal, Budapest, 2018.

ksh.hu/docs/hun/xftp/idoszaki/mo/mo2017.pdf (Elérve: 2019. 04.18.)

${ }^{28}$ Központi Statisztikai Hivatal. Gyermekvállalás és gyermeknevelés. Központi Statisztikai Hivatal, Budapest, 2011. ksh.hu/docs/hun/xftp/idoszaki/pdf/gyemekvallalasneveles.pdf (Elérve: 2019.04.18.)

${ }^{29}$ Spéder Z, Kapitány B. A termékenységi szándékok és a gyermekvállalási gyakorlat kapcsolata. Egy európai összehasonlító vizsgálat tanulságai. Demográfia.2014; 57:137-181.

30 Harjánné Brantmüller Éva, Lakos D, Karamánné Pakai A. Terhességmegszakítás serdülőkorban. Egészség Akadémia. 2016; 7 (4): 217-226. etk.pte.hu/public/upload/files/EgeszsegAkademia/2016 VII 4/04.Harjanne.pdf (Elérve: 2019.01. 16.) 